\title{
Kava Cultivation, Native Species Conservation, and Integrated Watershed Resource Management on Pohnpei Island ${ }^{1}$
}

\author{
Mark Merlin ${ }^{2}$ and William Raynor ${ }^{3}$
}

\begin{abstract}
For many centuries, the kava plant, Piper methysticum, a series of sterile clones of a truly wild Piper species, has been used in several high islands in remote Oceania, including Pohnpei in the Federated States of Micronesia. Until modern times, its use on all of these islands was largely restricted to chiefly, priestly, and medicinal use. Because of colonial suppression and/or the use of other nonindigenous psychoactive drugs, its use was abandoned on some of these islands. On other islands, such as Pohnpei, its use has increased greatly, with substantial changes in rank, gender, motivation, time, and place. This steep rise in its use has resulted in a large increase in its cultivation. On Pohnpei, intensification of cropping in upland environments is largely responsible for more than $70 \%$ loss of the remaining native, tropical rain forest since 1975 . This impact and other human activities endanger the unique upland biodiversity of this remote tropical island. Recent historical trends in forest exploitation, threats to biodiversity, and watershed disturbance on Pohnpei are discussed in this paper. The Watershed Conservation Plan and management benefits of the proposed Pacific-Asia Biodiversity Transect (PABITRA) are emphasized with permanent plot establishment for long-term monitoring.
\end{abstract}

Piper methysticum Fonst. F. is a tropical Pacific shrub in the pepper family, Piperaceae (Figure 1). It is known by various names in the tropical Pacific, such as kava, kava kava, 'awa, yagona, and sakau, and is propagated vegetatively, as are most of the Pacific's major traditional crops. Kava has been used for centuries, if not millennia, to produce psychoactive preparations. Its active principles, several lipidlike substances known as kava lactones, are concentrated in the rootstock and roots. These psychoactive chemicals are traditionally ingested by Pacific islanders, who generally drink cold-water infusions of kava stumps and roots that are chewed, ground, pounded, or otherwise macerated. Mind-altering kava

${ }^{1}$ Manuscript accepted 2 May 2004.

${ }^{2}$ Department of Botany, University of Hawaici at Mānoa, Honolulu, Hawai'i 96822.

${ }^{3}$ The Nature Conservancy, Pohnpei Island, Federated States of Micronesia.

Pacific Science (2005), vol. 59, no. 2:241-260

(C) 2005 by University of Hawai'i Press

All rights reserved preparations are, or once were, imbibed in a wide range of tropical Pacific Ocean societies (Lebot et al. 1992).

The first European explorers who landed on the islands of remote Oceania (i.e., eastern Melanesia, Polynesia, and Micronesia) encountered many societies in which kava drinking was an essential part of religious, political, and economic life. Cultivation and use of the plant has virtually disappeared from almost all of eastern Polynesia, as well as from Kosrae Island in Micronesia. But kava remains as an important psychoactive drug in parts of Melanesia (e.g., Vanuatu and Fiji), in most of the islands of western Polynesia (including Samoa and Tonga), and on Pohnpei Island in Micronesia. For centuries, kava had strong cultural significance for people in many tropical Pacific island societies, especially those in remote Oceania. Many have believed and some still do believe that kava has sacred powers, and therefore it can be classified as a "plant of the gods" (e.g., Schultes et al. 2001). The recent, rapidly growing interest in its use, often more recreational than sacred, and cultivation as a cash crop are important contemporary issues in a 


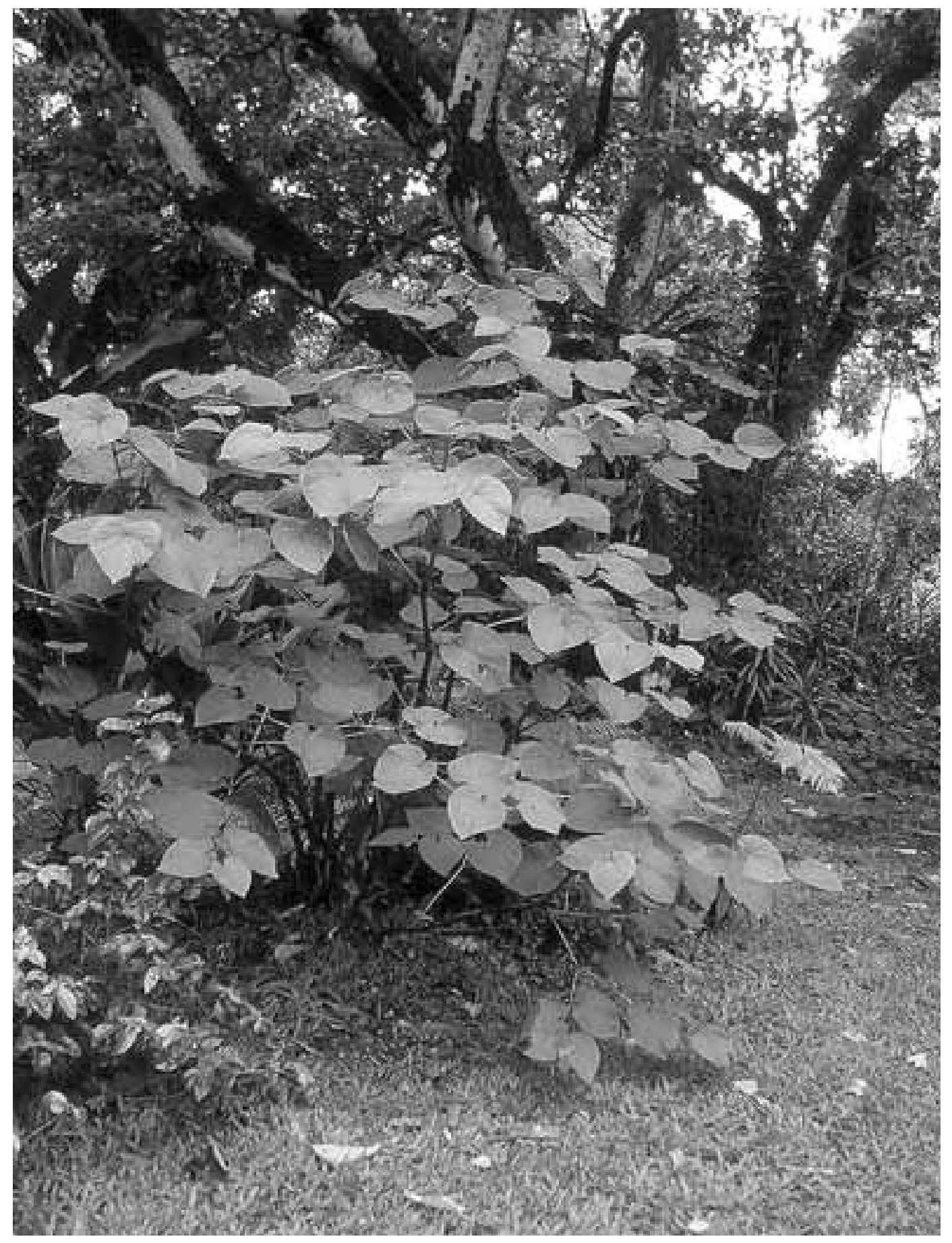

Figure 1. Kava, Piper methysticum, a tropical Pacific shrub in the pepper family, Piperaceae. 


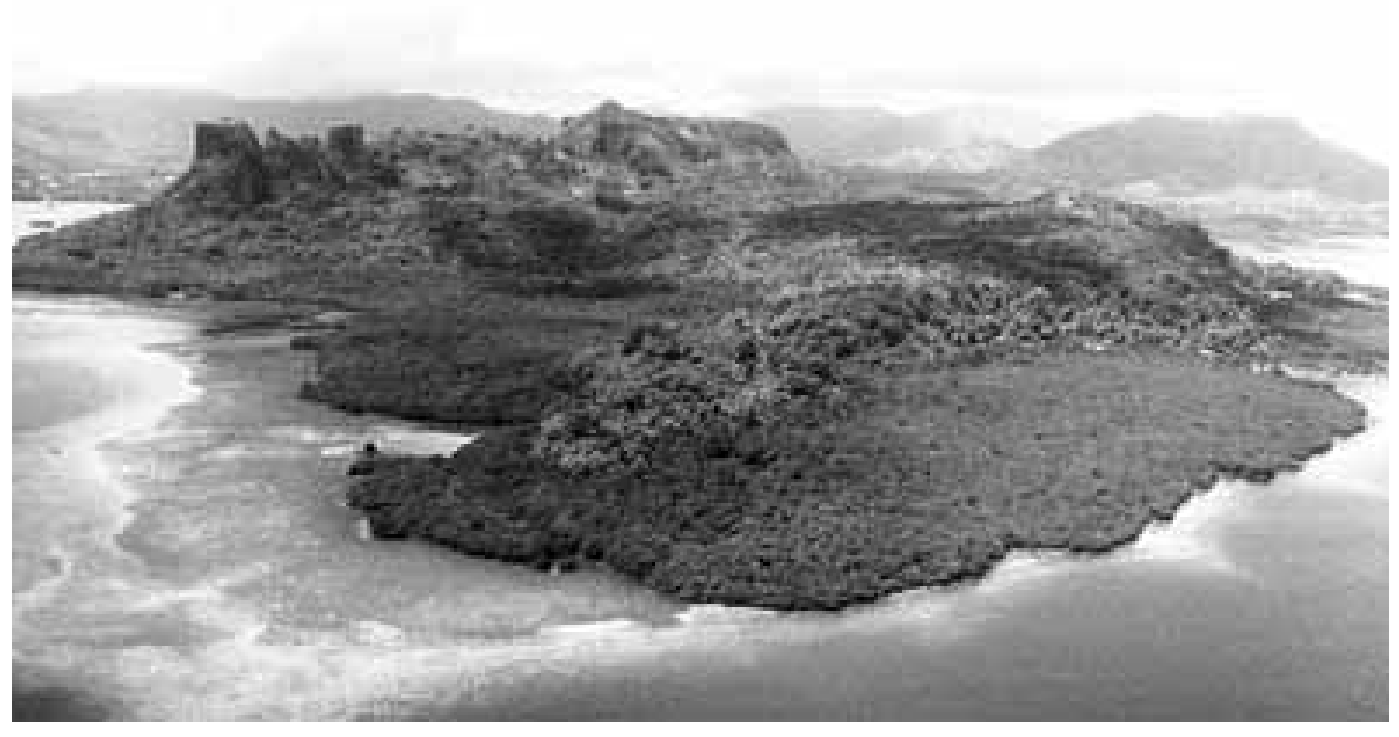

Figure 2. Aerial image of Pohnpei Island seen from the northwest.

number of tropical islands including Pohnpei. In fact, Pohnpei is the only Micronesian island where kava is still openly cultivated and traditionally, as well as recreationally, consumed. On Pohnpei kava is known as sakau, and in this paper it will be referred to by that name.

During the last decades of the twentieth century, use and cultivation of kava spread well beyond the areas of traditional use among Pacific islanders. This included a huge surge in use of kava products in several areas of Europe, North America, Australia, and elsewhere. On some tropical Pacific islands, in recent times, the traditional, strict controls on the use of kava as a sacred drug plant have been eliminated. For example, in parts of Vanuatu, Fiji, and Pohnpei, kava has become a source of a mind-altering beverage consumed by a greatly expanded part of the population with both societal and environmental consequences. This study focuses on the ecological impact of kava cultivation on the high volcanic island of Pohnpei in the Federated States of Micronesia (F.S.M.), with reference to recent watershed resource management efforts to deal with this and other human-related biodiversity threats. The potential benefits of the Pacific-Asia Biodiversity Transect (PABITRA) network, with its proposed field research for biodiversity conservation and ecological integrity, are emphasized as complementing the management efforts of the Conservation Society of Pohnpei and those of The Nature Conservancy.

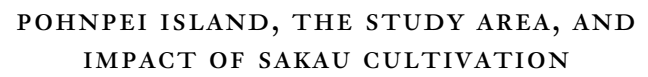

Pohnpei, a high volcanic island, is located at approximately $7^{\circ} \mathrm{N}$ latitude and $158^{\circ} \mathrm{E}$ longitude and covers $334 \mathrm{~km}^{2}$ of land with its highest elevation $791 \mathrm{~m}$ above sea level (Figures 2 and 3). It is the largest and tallest island in the F.S.M., traditionally referred to as part of the eastern Carolines island group. Before 1980, sakau was consumed on Pohnpei mainly in connection with feasts, funerals, and other cultural events. However, over the last two decades, sakau has grown in importance as a major cash crop, both for the local market, mainly kava bars, and for export to Pohnpeians and others overseas. More than a million pounds of sakau entered the commercial 


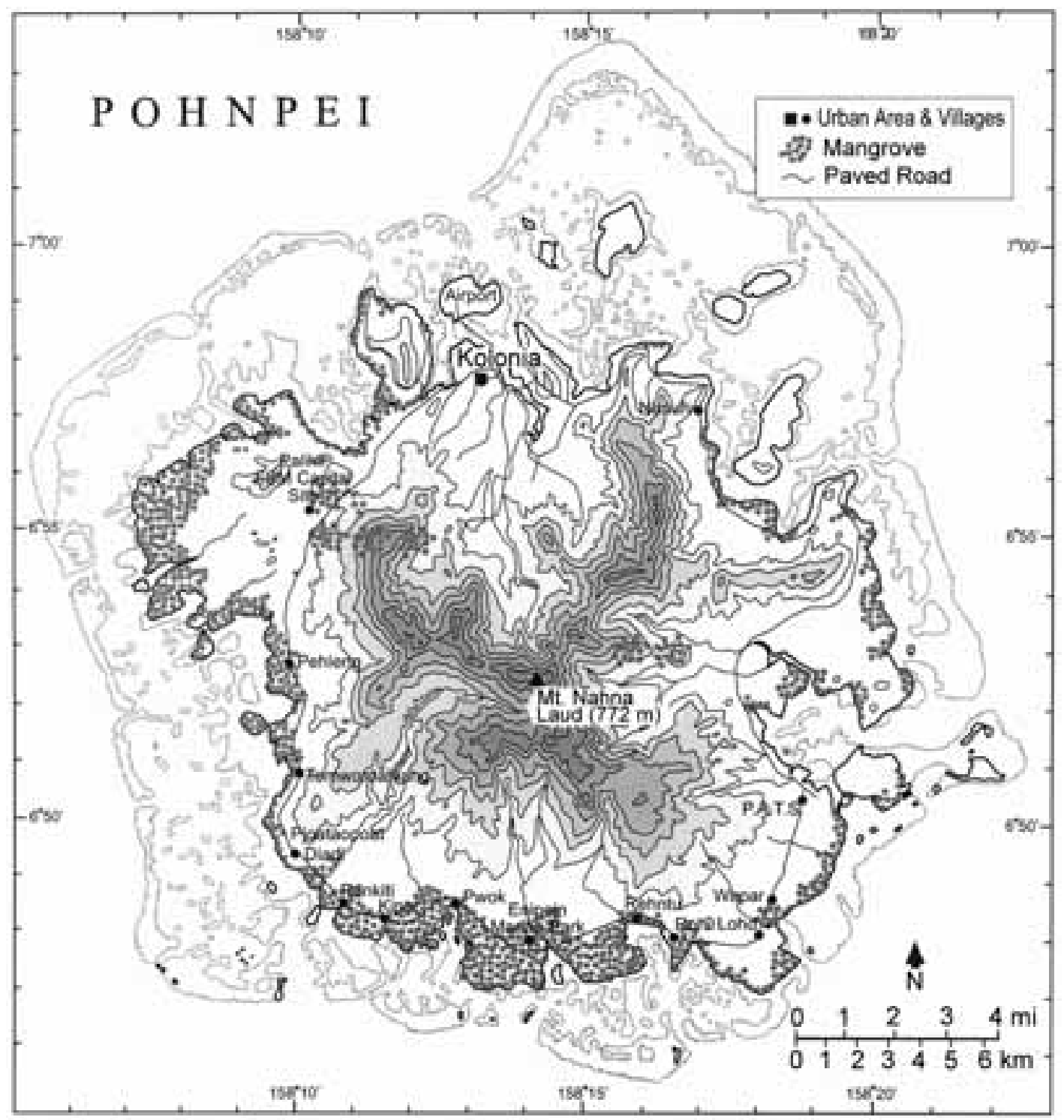

Figure 3. Map of Pohnpei Island, Federated States of Micronesia.

economy in 1996, generating at least US\$3 million for local growers and business people (J. Yakana, The Nature Conservancy, 1996, pers. comm.). Regrettably, this huge growth in sakau production led to widespread deforestation. Since $1975,70 \%$ or more of the previously intact native forests of Pohnpei
( $\sim 12,000$ ha) have been degraded, principally because of greatly increased cultivation of sakau. The following discussion outlines the historical and cultural trends involved in the rise of sakau as both the major cash crop and the principal environmental threat on Pohnpei. 
The sakau plant, considered sacred by the majority of the island's inhabitants even today, is the central feature of Pohnpeian social and cultural life. Among other things, sakau is used to acknowledge new titles or ranks, to ask forgiveness, honor and welcome visitors, seek marriage, celebrate birthdays, bring together villagers, seal agreements, and bury the dead (Reisenberg 1968, Merlin et al. 1992, Raynor 1994). Traditionally consumed only by people in the chiefly ranks, after World War II use of sakau became much more widespread and currently is a nightly ritual for a large percentage of the island's population.

However, as already noted, during the latter part of the twentieth century the cultural expansion of local sakau use, along with a rapidly growing, commercial demand for the crop in both local and export markets, led to increased cultivation, much of it at the expense of Pohnpei's native forests. The relatively recent movement of sakau cultivation into Pohnpei's upland rain forests has raised much concern. In comparison with some other tropical Pacific islands, the forests and coral reefs of Pohnpei are still relatively intact. For example, Pohnpei is one of only three islands in the Pacific more than 5 million yr old that still has substantial natural forest cover (Paulay 1994).

In fact, Pohnpei still has the largest intact native upland rain forests and mangroves in all of Micronesia, with some of the most diverse and unique vegetation and wildlife in the Pacific region. The forests of Pohnpei contain about 270 species of plants, of which 110 (ca. $41 \%$ ) are endemic to Pohnpei. Sixteen percent of the island's 50 bird species are also endemic to Pohnpei. In addition, there are at least 25 species of terrestrial tree snails, three species of fish, and a skink species that are endemic to the island. Pohnpeians depend on a number of these species for subsistence and income. In addition, the forests of Pohnpei provide important watershed benefits, storing, filtering, and slowly releasing water into the island's numerous springs, streams, and rivers, while protecting the island's lowlands, lagoon, and reef from sedimentation and degradation.
Although Pohnpeians have always made use of their forest resources (Raynor 1994), these resources are in greater danger today than ever before. However, accelerated forest loss, brought on mainly from agricultural clearing, chiefly for sakau, has fostered conservation efforts over the past two decades based on local concern for the natural heritage of Pohnpei. A natural resource management program has been developed to monitor and control the impact of sakau cultivation.

\section{HISTORICAL OVERVIEW}

For centuries sakau has been an integral part of the religious, economic, political, and social life of Pohnpei. Informants agree that sakau is an extremely special plant, because it actually exceeds all other plants and animals, including humans, in its wabu (respect) value (e.g., see Ashby 1990, Anson and Raynor 1993). Sakau is the central element of the ritual feasts (kamadipw en wabu) held each year for the paramount chiefs to celebrate the opening of the yam season and accompanies all nopwei (ceremonial first offerings to the gods and chiefs) of the major seasonal crops-breadfruit and yams. Because of its wabu value, sakau is presented and prepared anytime one meets with chiefs or senior lineage members, when asking favors or forgiveness for particularly serious transgressions, for marriage ceremonies, and various other occasions when a commoner needs to meet with higher-ranked people or the paramount chiefs. Despite recent trends in commercialization, sakau continues to hold its central place in the cultural and social systems of Pohnpei.

Pohnpei legend suggests that sakau was introduced as a "gift from the gods." According to one legend, sakau fell to earth in several forest areas on Pohnpei and began to grow. In these areas, known as diwi, sakau grew wild and often reached very large size. Traditionally, people visited these areas to harvest small amounts for personal use and collect planting materials for growing on their lands. Over the last few decades, people claim that most of the diwi have been destroyed by greedy commercial harvesters. 
FROM TRADITIONAL TO COMMERCIAL USE

Although sakau consumption was reserved mainly for the higher-ranking members of the culture, during the Japanese mandate (1914-1945) its use was even more highly restricted and strict punishments were dealt out to offenders. However, as noted earlier, since World War II, consumption has increased steadily, extending more and more to the general populace. Before the opening of the first sakau bar in Kitti in 1972, sakau was neither bought nor sold. Generally, each Pohnpeian man had his own sakau, and the plant itself was considered a prestige crop, useful only in the realm of traditional activity. Having a lot of sakau marked a man as productive and successful, able to provide for his family and community at all times.

After the opening of the first commercial markets on Pohnpei, commercial sale of sakau began to increase, especially in the urban center of Kolonia, where consumers rapidly outnumbered growers as the island's urban center doubled in population over three decades from 1970 to 2000; the current total human population on Pohnpei is about 34,500 (F.S.M. 2000), but probably reached $\sim 38,000$ by 2002 . As the cash economy continued to grow, fewer people had the time to grow sakau, although practically everyone who participates in the local culture needs sakau. Subsequently, a cash market also appeared in the mid-1970s for whole sakau plants (with branches intact), which is preferred for a variety of cultural uses.

The event that really increased the commercialization of sakau, however, was the severe 1982-1983 El Niño drought, the worst ever recorded on Pohnpei. By the second month of the drought, much of the island's lowland sakau crop was dying in the fields, and desperate farmers sold what they could to avoid total loss. At the same time, observant farmers noticed that the forests remained moist during the drought. Concerns about future reliability of rainfall drove planting into the forest, where rainfall is more consistent and reliable and soil fertility is higher.

Cultivators realized that sakau grows faster in newly cleared forest areas, and as the local demand picked up this became a key factor for "upland" sakau farming. Since 1983, most of this new upland sakau planting has occurred on public lands. Because of the distance and effort required to walk to, cultivate, and carry out sakau from the interior forests, typical sakau growers have gradually shifted from mature Pohnpeian men (Obl en Pobnpei) to younger males, 15 to 30 yr old. Sakau cultivation became the most lucrative option open to young men living in rural areas, who are mostly uneducated and unskilled, lack access to family lands, and have only limited traditional farming knowledge. The attraction of the upland forest cultivation was further strengthened because having large quantities of sakau not only has provided a sizable income in the current, rather stagnant, economy but also has often enhanced the young grower's status in his family and community.

Because of the use of public lands and the increased focus on production of larger plants in a shorter time frame, cultivation methods have also gradually shifted to those favoring commercial production. This includes practices that degrade forest habitat such as total overstory clearing and clean weeding; these increase production in the short term but can cause long-term environmental problems. These environmentally unsustainable practices are hardly ever carried out on private lands, but they became the rule for sakau plots in public forest lands (Dahl and Raynor 1996).

Sakau became the major income source for much of the island's rural population, generating millions of dollars a year in the rural economy. By the end of the twentieth century, 4,000-5,000 people (ca. 15\% of the population) were engaged in sakau production, most as their primary source of income. The domestic market then consisted of about 50 licensed sakau bars, a number of retail stores, and numerous unlicensed temporary sakau bars (Figure 4), with combined consumption estimated at 477,000 kg/yr (J. Yakana, The Nature Conservancy, 1996, pers. comm.). Local demand is mainly for fresh plants, processed (roots pounded and 


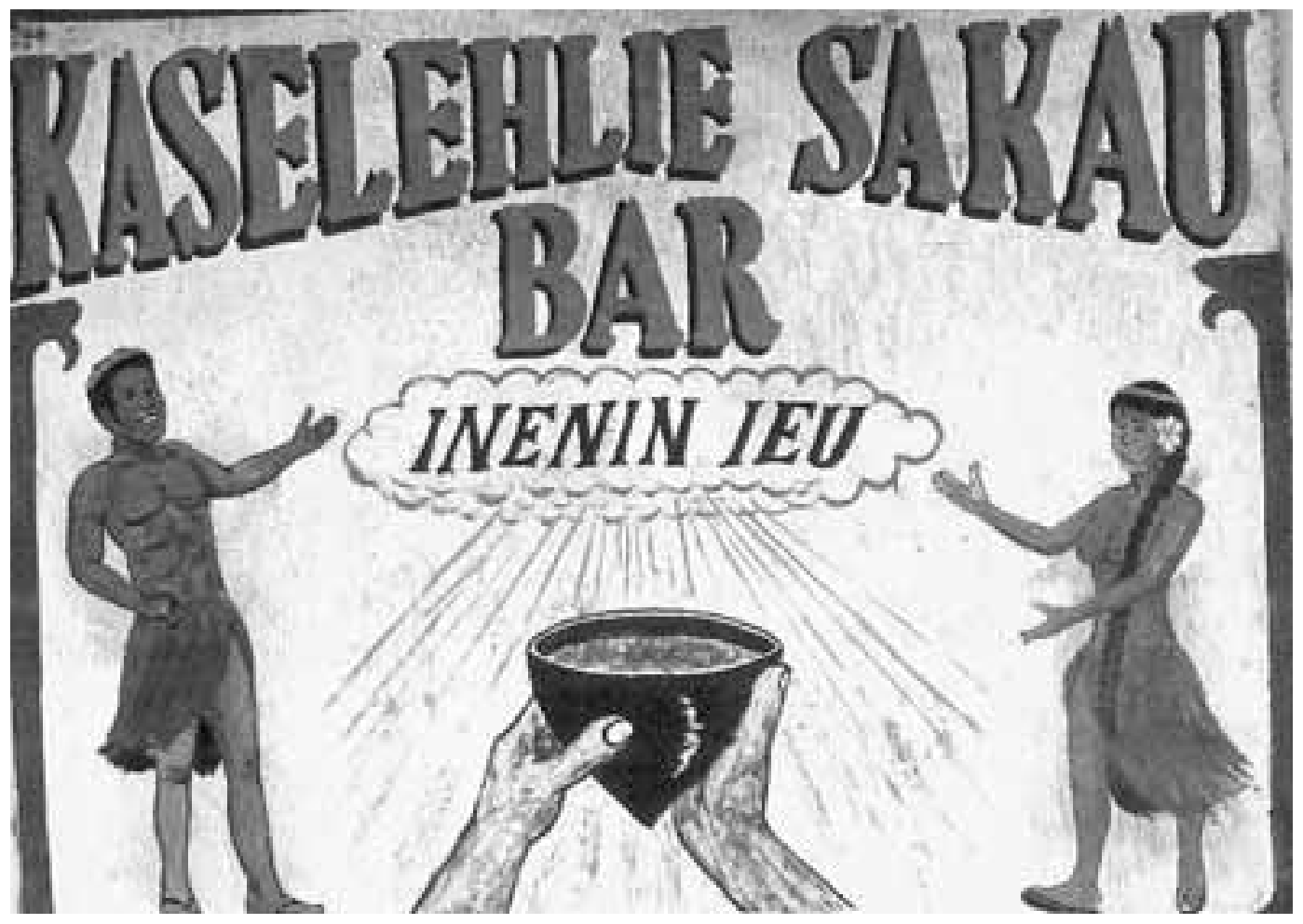

Figure 4. Sign for one of the many sakau (kava) bars on Pohnpei Island.

squeezed) fresh and bottled extract, and pounded and frozen roots. The export market in 1995-2000 (mainly to expatriate Pohnpeians living in Guam, Saipan, Hawai' $i$, and the U.S. mainland) was estimated at 40,000 $\mathrm{kg} / \mathrm{yr}$ for pounded and frozen roots and liquid extract. Another $660,000 \mathrm{~kg}$ was being harvested annually for customary use and personal consumption by farmers and their extended families. By the late 1990s, approximately 2,500-5,000 ha of sakau were planted, and most of this is in the upland forests, where soils are richer and sakau grows quickly to a marketable size.

\section{SUMMARY OF UPLAND KAVA CULTIVATION} IMPACT

The growth of kava cultivation over the last three decades has had mixed impacts on the economy, environment, and culture of Pohn- pei. A greatly increased demand for kava has been stimulated by the strong move toward a cash economy and preference for wage labor; however, substantial environmental damage has occurred as growers have moved onto public lands in the island's upland forests, where conditions favor commercial production, at least in the short term, because of sufficient natural moisture and high, but transient, fertility. Stereoscopic analysis of aerial photography, supplemented by field reconnaissance, indicates that in only $27 \mathrm{yr}(1975-$ 2002) about 12,000 ha of Pohnpei's intact native forests had been heavily disturbed or destroyed; indeed, between 1975 and 2002, the area of upland forest alone was reduced from 18,800 ha to 10,500 ha (see Figure 5). It is safe to say that no greater environmental disaster has befallen the island in the more than 2,500 yr since Pohnpei has been inhabited! 

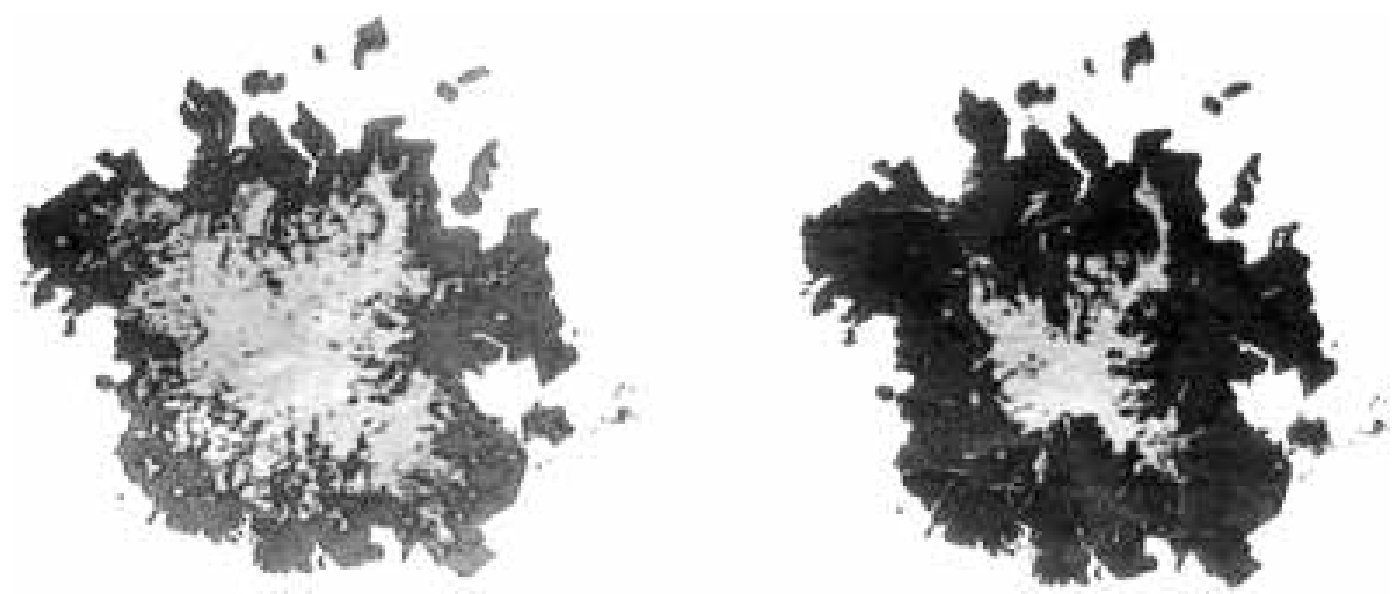

FigURE 5. Maps representing remote sensing data that documented decline in areal extent of native upland rain forest on Pohnpei Island from $42 \%$ in 1975 (left map) to $15 \%$ in 1995 (right map).

THE POHNPEI WATERSHED FOREST RESERVE SITE CONSERVATION PLAN

Beginning in 1982, island foresters and scientists began to notice an increase in deforestation. By 1987, the Pohnpei Watershed Forest Reserve was established by law (State Law 1L-128-87: The Pohnpei Watershed Forest Reserve and Mangrove Protection Act of 1987) in response to acknowledgment that Pohnpei's interior was being rapidly deforested. The reserve encompasses 5,100 ha $(13,000$ acres $)$ of the central upland forest and is home to most of the island's biodiversity, including broadleaf, palm, ivory nut, and montane cloud forests containing approximately 270 plant species (110 endemic), 50 bird species (13 endemic at the species and subspecies levels), and numerous other indigenous and endemic animals. However, community involvement in the development of the law was virtually nonexistent in the early years after it was passed, and the proposed rules and regulations, failing to recognize traditional Pohnpei resource use and authority, were universally rejected. As a result, government boundary survey teams were turned back by angry villagers around the island.

These setbacks led to the formation of the Watershed Steering Committee in 1990, an interagency task force made up of representatives from several Pohnpei State Government agencies, community leaders, and nongovernment organizations. The Nature Conservancy began working at the site in 1992, and assisted the Watershed Steering Committee to initiate a watershed education and negotiation program. Over $2 \mathrm{yr}$ the program was extended to the entire island of Pohnpei. Two major changes were unanimously insisted upon by local communities in over 200 meetings: first, paramount chiefs and their village representatives (soumas) need to be partners in the management process; and second, environmentally sustainable management should be extended beyond the Watershed Forest Reserve to encompass the entire island, from the mountains to the reefs.

Beginning in 1992, the government's effort to develop a community-based management program began to attract outside interest. The South Pacific Regional Environmental Programme provided funding and technical assistance as part of the South Pacific Biodiversity Conservation Programme. The Asian Development Bank soon followed, advancing a technical assistance package through The Nature Conservancy that included development of a Geographic Information System, new aerial photography, and identification 
of compatible enterprise alternatives. It also resulted in the development of the Pohnpei Watershed Management Strategy, which recognizes the central role of communities in determining resource use and managing natural environment and seeks to ensure the sustainable management of Pohnpei's natural resources. This strategy led to the initiation of the Pohnpei Community Planning Program, an innovative attempt to support the island's communities as the primary managers of their biological resources. The program aims to develop coordinated management within and between communities that will maintain subsistence and cash resources while also protecting the island's remarkable biodiversity. It also hopes to develop a legal and administrative framework for equitable comanagement between government and customary authorities on the island.

PABITRA, a network of the Ecosystem Division in the Biodiversity Task Force of the Pacific Science Association, has the potential to play an important role in assisting the Pohnpei Community Planning Program to achieve these multiple management goals. Under the leadership of Dieter MuellerDombois and other network scientists, PABITRA has begun training teams of local and other traditional and scientific experts (e.g., in Fiji and Samoa) and has proposed permanent plot establishment along ocean-to-mountain transects for long-term environmental monitoring on a variety of tropical Pacific islands, including Pohnpei (see the PABITRA Web site [http://www.botany.hawaii.edu/pabitra/] and other articles in this issue of Pacific Science). This ecological monitoring has the potential to assist the efforts of those concerned Pohnpeian governmental agencies, nongovernmental agencies, and local citizens by providing a continuum of biological and physical data relevant to economic, legal, administrative, and resource management decision making.

\section{CONSERVATION TARGETS AND STRESSES}

As a result of the Pohnpei Community Planning Program, the Conservation Society of Pohnpei, a nongovernmental organization strongly involved with local environmental issues, chose seven conservation targets for coordinated resource management. These include three system targets (tropical montane cloud forest, broadleaf/palm forest, and headwater streams) and four species targets (forest birds as a whole group, the Pohnpei shorteared owl, bats, and endemic snails).

\section{Tropical Montane Cloud Forest}

Pohnpei's tropical montane cloud forest has been described as the lowest-elevation cloud forest in the world. Tropical montane cloud forest is the result of environmental factors, including extremely high rainfall $(>1,125$ $\mathrm{cm} / \mathrm{yr}$ ), wind, and rocky substrate (Figure 6). On Pohnpei, above $600 \mathrm{~m}$, the trees are stunted (typically 3-6 $\mathrm{m}$ or less). On the highest, wind-blown summits, trees reach only $1.2-1.5 \mathrm{~m}$ in height. Cyathea ponapensis and Gynotroches axillaris are typical dominants, but Astronidium ponapense, Garcinia ponapensis, Ilex volkensiana, Cinnamomum caroliniense, Elaeocarpus kerstingianus, Glochidion sp., Syzygium caroliniense, Rapanaea caroliniensis, and Campnosperma brevipetiolata all attain dominance in some areas. Trails in this forest become canals of mud after very little use. Pohnpei tropical montane cloud forest encompasses a variety of other important communities and species, including montane freshwater perched marshes, endemic Pandanus patina forests, the Pohnpei Island skink (Emoia ponapea), the long-billed white-eye (Rukia longirostra), a number of endemic tree snails, and the extremely rare Pohnpei mountain starling (Aplonis pelzelni [see Buden 1996]). Currently, the top stress on this forest type involves the alteration of composition/ structure, mainly as the result of occasional human visitors and introduced animals and plants. The trampling by people and alien hoofed mammals that root or browse in these cloud forests, which originated in the absence of such animals, rapidly breaks down tropical montane cloud forest, and the component trees are not able to withstand these impacts. Invasive plants, especially grasses, rapidly colonize and outcompete native species after these kinds of disturbances. 


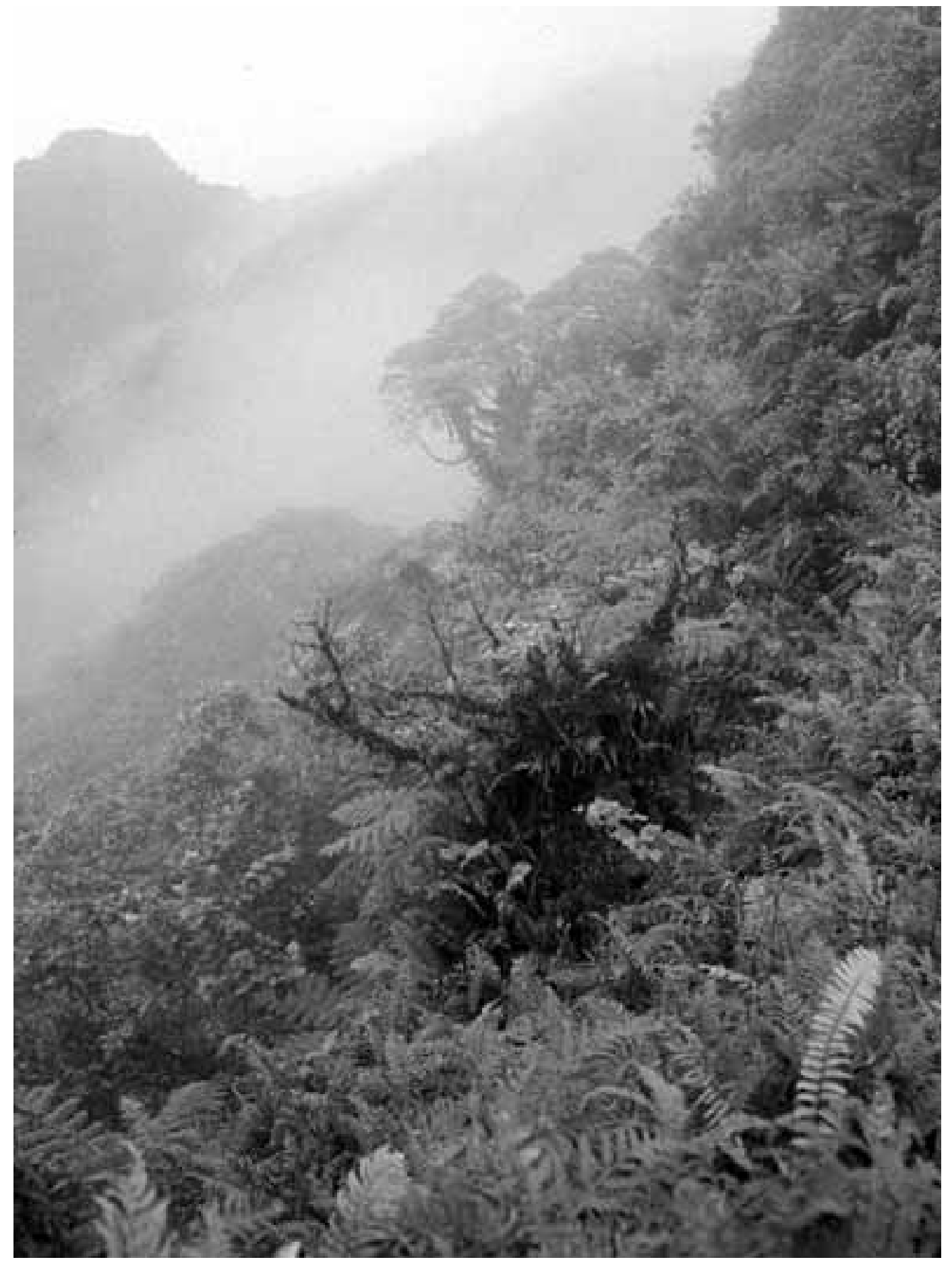

Figure 6. Tropical montane cloud forest on Pohnpei Island. 


\section{Broadleaf/Palm Forest}

This vegetation type combines the remaining native broadleaf and palm forests that make up the majority of Pohnpei's upland forests. Several forest types make up the upland forest resource, distributed on the island in relation to altitude and, to a lesser extent, drainage. Broadleaf forest is the most widespread and is dominated by Campnosperma brevipetiolata, Elaeocarpus carolinensis, and other tree species (for example, Parkia korom, Palaquium karrak, Myristica insularis, Cinnamomum caroliniense, Ficus tinctoria, Barringtonia racemosa, Terminalia caroliniensis, and Cynometra ramiflora). Almost pure stands of the endemic palm Clinostigma ponapensis are found on upperelevation ridges. Upland swamp forest, characterized by the endemic ivory nut palm, Metroxylon amicarum, occurs in scattered patches. The broadleaf/palm forest matrix encompasses a number of other important targets, including approximately 270 species of plants (110 endemic), 50 species of birds (13 endemic species and subspecies), the Pohnpei Island skink, endemic tree snails, the Pohnpei flying fox (Pteropus molossinus), the Polynesian sheath-tailed bat (Emballonura semicaudata), and the Micronesian swiftlet (Collocalia inquieta). The current stresses on broadleaf/ palm forest include habitat fragmentation, altered composition/structure, and habitat destruction or conversion. Recent work by The Nature Conservancy has documented a conversion of almost two-thirds of the broadleaf/palm forest $(10,000 \mathrm{ha})$ to other vegetation types between 1975 and 1995, mostly agriculture, especially sakau cultivation.

\section{Headwater Streams}

These aquatic waterways are some of the most important and complex systems on Pohnpei Island. Due to the island's elevation (up to $795 \mathrm{~m}$ ) and high rainfall, the streams of Pohnpei are well formed and biologically diverse (e.g., see Buden et al. 2001). In addition, the water they provide is absolutely essential to downstream habitats, including coastal freshwater marshes, swamp forests, mangrove forests, lagoons, and coral reefs. Headwater streams also encompass a number of endemic species, including freshwater fish such as the vertical hover goby, Parioglossus verticalis, and other gobies including Stenogobius spp., Stiphodon spp., Sicyopus nigriradiatus, Sicyopterus lividus, Sicyopterus eudentatus, and Lentipes spp.; a freshwater eel, Anguilla sp.; freshwater shrimp; dragonflies and damselflies such as Pacificothemis esakii, Hemicordulla baluco, Teinobasis ponapensis, Teinobasis nigrolutea, Teinobasis fortis, Teinobasis ariel, Teinobasis aeride, Stolephorus multibranchus, and Agrionoptera sanguinolenta. Habitat fragmentation, habitat destruction or conversion, pollution, thermal alteration, and sedimentation are the major stresses on headwater streams, caused mainly by the cultivation of sakau along stream banks and subsequent homesteading-related forest conversion.

\section{Forest Birds}

Forest birds have been given special focus as a species group because managing and protecting the forest alone would not necessarily guarantee the survival of birds that nest in the forests of Pohnpei. Forest birds include 32 species that nest in Pohnpei's forests, including 13 species and subspecies endemic to Pohnpei such as the long-billed greater white-eye (Rukia longirostra), Pohnpei lory (Trichoglossus rubiginosus), Pohnpei flycatcher (Myiagra pluto), Pohnpei fantail (Rhipidura kubaryi), Caroline Islands ground dove (Gallicolumba kubaryi), purple-capped fruit dove (Ptilinopus phorphyraceus), Micronesian imperial pigeon (Ducula oceanica), Caroline Islands reed warbler (Acrocephalis syrinx), Caroline Islands white-eye (Zosterops semperi), Micronesia kingfisher (Halcyon cinnamomima), gray white-eye (Zosterops cinerea), blue-faced parrotfinch (Eurythrura trichroa ssp. clara), and the cicada bird (Coracina tenuirostris ssp. inseperatum). Stresses on Pohnpei's forest birds include habitat destruction or conversion, species loss, extraordinary predation/ parasitism/disease, and habitat fragmentation. Most of the stresses are caused by human incursion into the upland forests for cultivation of sakau and settlement. Along with humans, 
introduced animals, especially cats and rats and to a lesser degree pigs and ants, are believed to be major predators of forest birds. Invasive plants become established in settlement areas and further limit the birds' major native plant food sources (Engbring et al. 1990).

\section{Pohnpei Short-Eared Owl}

The Pohnpei short-eared owl (Asio flammeus ponapensis) was considered a separate target because, unlike its avian cousins, it nests in holes in and hunts in the island's open grasslands and savannas. Therefore management of the island's forests, or even forest birds, would not protect the short-eared owl. The short-eared owl's survival depends on the protection of native and nonnative grassland and savanna. The Micronesia kingfisher ( $\mathrm{Hal}$ cyon cinnamomima), which also hunts in the savanna area, is another species that depends on the same ecosystems for its survival. The kingfisher is also occasionally eaten by the short-eared owl. The main stresses on the short-eared owl and its habitat include alteration of natural fire regimes and habitat destruction or conversion, caused mainly by annual burning of many of the island's grasslands and savannas during the dry season (January-March) by hunters to bring introduced Philippine deer out into the open. Extraordinary predation/parasitism/disease may be another stress, especially from introduced cats and rats that may prey on the young of the Pohnpei short-eared owl.

\section{Bats}

Although Pohnpei's bats, which include the endemic Pohnpei flying fox (Pteropus molossinus) and the native Polynesian sheath-tailed bat (Emballonura semicaudata), nest below the upland forests, their importance to the island's various forest types as major pollinators and seed distributors led to their selection as a separate conservation target. In addition, the Pohnpei flying fox roosts in groups in the island's agroforest areas, swamp forest, and mangroves, and the Polynesian sheathtailed bat has been known to live in hollow dead trees in mangrove forests, so they need to be managed on a broader scale than just the upland forest. The caves of the sheathtailed bat may also host other insect biodiversity that has not yet been studied. Top stresses to the bats of Pohnpei include species loss, habitat destruction or conversion, and habitat disturbance. After the ban on flying fox exports to Guam in the early 1990s, the direct harvest of these animals decreased considerably, but they still face a number of threats from forest conversion and habitat disturbance from introduced animals. Some of the sheath-tailed bat's caves have also been disturbed by hikers and the ecotourist businesses; local guides sometimes disturb the bats, encouraging the animals to fly out of their caves or dead trees, which amuses the tourists. This continued and regular disturbance has led to the abandonment of several sheath-tailed bat caves.

\section{Endemic Snails}

The numerous endemic terrestrial snails of Pohnpei are some of the least-studied species on the island. Although most of the remaining tree snail population is located in the montane cloud forest, the threats to their survival will not be eliminated by simply managing these areas; thus they have been treated as a separate conservation target. The known endemic species of terrestrial snails on Pohnpei include Trochomorpha conoides, Trochomorpha nigritella tolotomi, Trochomorpha nigritella fuscata, Trochomorpha nigritella paucispira, Trochomorpha nigritella, Trochomorpha contigua nanalauti, Trochomorpha contigua, Trochomorpha carolinae, Trochomorpha kuesteri monticola, Trochomorpha kuesteri, Liardetia doliolum, Dendrotrochus ponapensis, Palline micramyla, fokajdon callizonus, Fokajdon tumidulus, Palikirus ponapicus, Palikirus cosmetus, Roimontis tolotomensis, Kubaryiellus kubaryi, Russatus nigrescens, Wrayanna soluta, Thaanumella cookei ponapensis, Thaanumella cookei, Thaanumella angulosa turita, Thaanumella angulosa, Ponapella pibapiha, Partula martensiana, Partula guamensis, and Partula emersoni (B. D. Smith, Marine Laboratory, University of Guam, 2004, pers. comm.). The main stresses affecting terres- 
trial snails on Pohnpei include extraordinary predation, parasitism, and disease, and, to a much lesser extent, habitat fragmentation. In the 1950s, the Trust Territory (USA) government introduced the rosy wolf snail, $E u$ glandina rosea, and the parasitic flatworm Platydemus manokwari (Eldredge and Smith 1994) to control the giant African snail (Achatina fulica), a serious introduced agricultural pest. Both these species were observed up to the cloud forest in Pohnpei, along with shells from endemic Pohnpei snails showing alien predation effects during a 1992 snail population and distribution survey undertaken by the Pohnpei State Government, The Nature Conservancy, and the University of Guam.

\section{CRITICAL THREATS AND STAKEHOLDERS}

A number of critical threats to the biodiversity of Pohnpei have been identified in recent years, including five that were deemed most serious. According to The Nature Conservancy, these serious threats in order of importance are invasive animals, agricultural clearing, hunting, homestead development, and recreation.

\section{Invasive Animals}

Some invasive animals are major predators and parasites affecting the native fauna of Pohnpei, especially endemic snails, forest birds, and bats. Alien animals that have had the most impact on native species are the predatory snail Euglandina rosea, the introduced flatworm Platydemus sp., and rats (especially Rattus rattus, which is a major predator of native forest nesting birds in other islands and probably also on Pohnpei). Domestic and feral cats, introduced in the 1800s, currently exist in large numbers throughout the island and probably are a major predator of native birds. Pigs may also be a predator, especially of ground-nesting species such as the Caroline Islands ground dove and the shorteared owl. The Philippine deer, Cervus mariannus, has also been introduced on Pohnpei and may have a negative impact on at least some native species (Wiles et al. 1999). Introduced insects, especially mosquitoes (the vector for bird malaria, which has wiped out numerous native bird species on other islands) as well as alien ants, are most likely also having a negative impact on forest bird populations.

\section{Agricultural Clearing}

Clearing for farming, mainly for sakau as noted earlier, has been identified as a serious threat for Pohnpei's forests, especially in recent decades. All targets except the tropical montane cloud forest are currently impacted by this threat, which has been exacerbated by rapid population growth and a rapid growth in the cash economy. As mentioned previously, aerial photography and vegetation mapping revealed that intact native forest on Pohnpei had been reduced from $42 \%$ of the island's land area to only 15\% between 1975 and 1995 and that the loss of native forest continued over the next 7 yr (into 2002) but at a considerably slower rate (492 ha/yr between 1975 and 1995 to $153 \mathrm{ha} / \mathrm{yr}$ between 1995 and 2002). However, whether or not the watershed project discussed later in this paper was responsible for the declining rate of forest clearing is not clear because it may be that there is no more forest to cut except on steep slopes. In any case, the local, commercial market for sakau has also grown rapidly in the last two decades. Pricewise, local per-pound prices for sakau have increased tenfold in the last 15 yr. Forest conversion increases erosion, which exacerbates the downstream impacts of sediment on mangroves, lagoons, and coral reefs. Finally, forest conversion results in a loss of species diversity. Because terrestrial endemism is relatively high, the local extinction of a species could be equivalent to its complete loss. The upland forest, because of clearing and other forms of degradation, may already be close to a critical threshold in terms of habitat value.

\section{Hunting}

The hunting of forest birds, mainly undertaken by younger (18-35 yr old) rural, relatively uneducated (high school or less) men, 
and now with guns, is another minor threat to forest birds. Species such as the Micronesian pigeon (Ducula oceanica) and the purplecapped fruit dove (Ptilinopus porphyraceus) have experienced drastic population reductions in recent years. Hunting also has indirect impacts on the short-eared owl. The owl nests in holes in the ground in savanna areas. Hunters burn the savannas whenever the weather is dry enough, because deer are attracted to the odor of ashes. Apparently, alien deer introduced for hunting associate ashes with tender new sprouts of grasses and ferns.

\section{Homestead Development}

With the rapid growth in population on Pohnpei Island, combined with in-migration of people from other islands after the island was declared the capital of the F.S.M., private lands have become increasingly fragmented. In addition, a number of younger Pohnpeians, especially those from large families, do not have access to land. Pohnpei's forested interior, mainly public land as a result of the German land distribution in the early 1900s, represents an attractive resource to these people. For a number of reasons, the last new land distribution by the government occurred in the late 1950 s, nearly three generations ago. This has led to "squatting" on public lands located around the Kolonia area and movement of people into the forested public lands above villages around the island. In addition, inland movement and settlement has been encouraged by the traditional leadership of the island, who still claim the central forested uplands as "kingdom" land that was never passed on to the German Kolonia government for distribution.

\section{Recreation}

Impact through recreational activities, mainly ecotourism, is a fairly minor threat to the short-eared owl and bats. The main threat to the native owl is "recreational" burning. Because few people value the island's savanna and grassland areas, burning them is not considered a serious offense, and many fires are started by children walking home from school or younger people playing with fire. Bats, especially the sheath-tailed bat in areas where regular ecotourism trails are located (e.g., Pwudoi Sanctuary and Pahntakai Waterfall), are, as noted earlier, often disturbed by tour guides, often encouraging the bats to abandon their roosts.

\section{STRATEGIES FOR FOREST CONSERVATION AND BIODIVERSITY PROTECTION ON POHNPEI}

Over the past decade, a number of strategies to enhance forest conservation and biodiversity protection have been developed by governmental agencies and nongovernmental organizations. Several are ongoing strategies and a few reflect new ideas. Three strategies ranked particularly high: promotion of lowland sakau cultivation, promotion of a "ranger" enforcement program, and demarcation of the watershed forest reserve boundary. Several other strategies ranked as medium in importance. The strategies are summarized as follows:

\section{Strategy 1. Promote Lowland Cultivation of Sakau}

The "Grow Low" Campaign has been a key component of The Nature Conservancy's strategy on Pohnpei. After 10 yr building up a substantial conservation capacity in the watershed forest reserve, The Nature Conservancy has recently convinced their local partners, the Conservation Society of Pohnpei, to take over the on-site management, including the campaign to encourage sakau growers to stop planting in the upland forest and move their crops back to the lowlands (Figure 7). A key component of the Grow Low Campaign strategy is a program of distributing planting information and small plastic bags for use as simple plant containers to assist farmers in getting a lowland-grown $s a$ kau crop started. By 2003, over 600,000 bags had been distributed to interested farmers. This simple method has dramatically increased the survival rate of lowland-grown sakau. After several months in small local nurseries, young sakau plants are eventually 


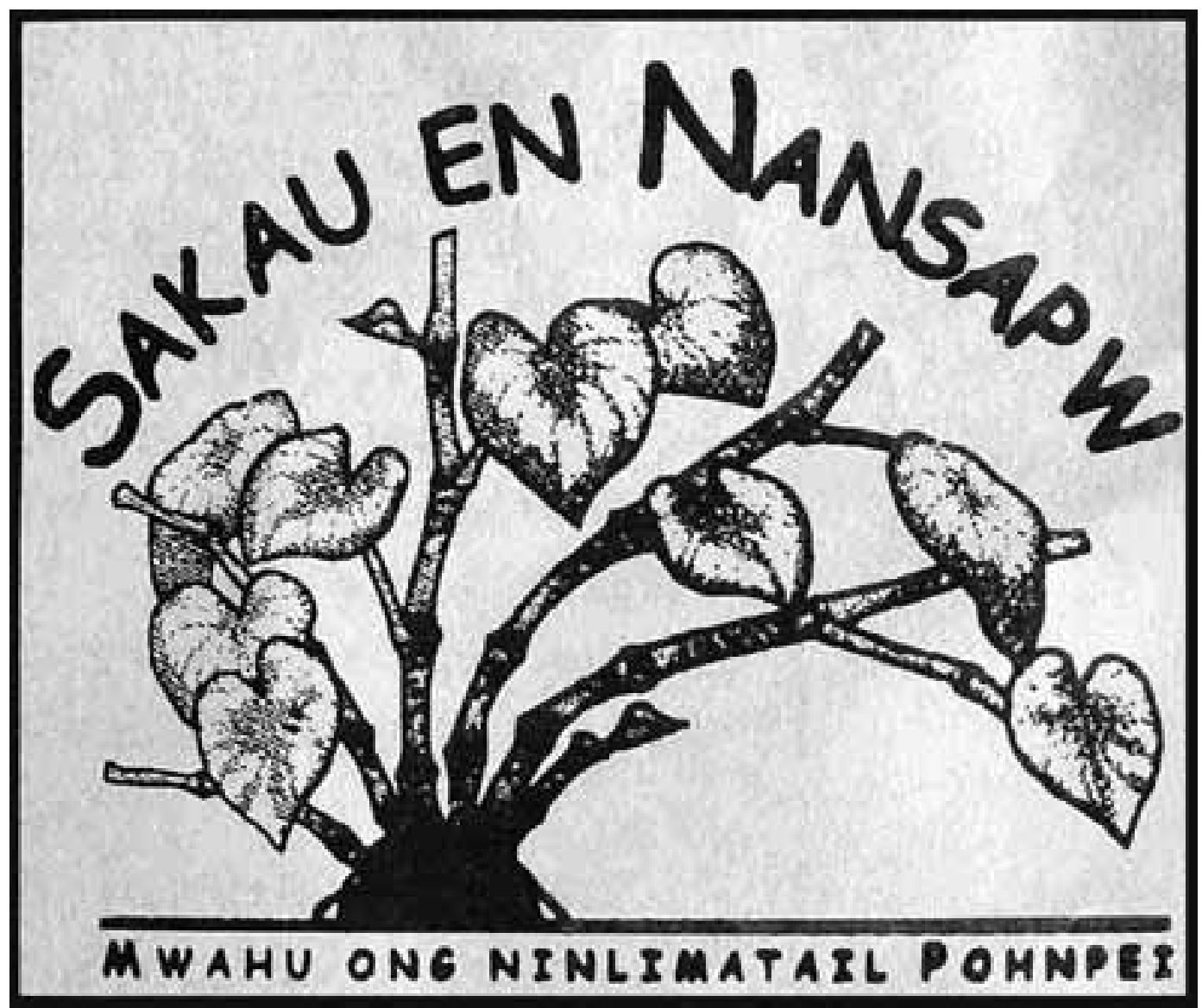

Figure 7. Logo for the sakau "Grow Low" Campaign (Sakau en Nansapw = "kava in the traditionally cultivated lowland regions").

transplanted into the field, usually under the shade of other trees.

This program has had a very positive reception among local farmers and has a lot of momentum. The goal is to have cultivators plant 3 million sakau plants in lowland forests near villages by 2006 . If achieved, this could replace all upland-grown sakau for local consumption and produce a large exportable surplus for the international markets.

The Grow Low strategy to eliminate upland forest cultivation of sakau will reduce agricultural clearing in these areas of relatively high native biodiversity. In addition, less human activity in the upland forest will help re- duce the introduction and spread of invasive plants and animals in these ecologically sensitive areas.

The Nature Conservancy has passed the implementation of this strategy to the Conservation Society of Pohnpei. Key partners in this strategy include The Nature Conservancy, traditional municipal and village chiefs, the Pohnpei State Government's Department of Economic Development and the Department of Land and Resource Management, the College of Micronesia Land Grant Programs, the U.S. Department of Agriculture Natural Resources Conservation Service, and, potentially, the PABITRA network. 
Strategy 2. Develop a State-Level Ranger Enforcement Program

Village chiefs in some parts of Pohnpei have appointed community conservation officers to help implement Community and $\mathrm{Mu}-$ nicipality Action Plans. Currently, there are over 250 young men and women who have been appointed as community conservation officers. They serve on a voluntary basis and are responsible for conservation education, promotion of sustainable development activities, and monitoring and enforcement of community-approved restrictions. The $\mathrm{Na}$ ture Conservancy has worked closely with the program, helping to build the capacity of community conservation officers through technical training, mobilization of funding, and strategic planning assistance. Surveillance and monitoring work of the conservation officers should lead to a decrease in agricultural clearing and hunting as well as a reduction in the spread of invasive plants and animals. Having villagers directly involved in protected areas management will also improve public awareness of the importance of the island's biodiversity and support of the need to conserve it. The Conservation Society of Pohnpei is the lead agency and will be assisted by The Nature Conservancy, the Marine and Environmental Research Institute of Pohnpei, the Pohnpei State Marine Resources Division and Forest Division, and the College of Micronesia.

\section{Strategy 3. Demarcate the Watershed Forest Reserve Boundary}

As a result of $10 \mathrm{yr}$ of public education and involvement, the island's traditional and government leaders now nearly unanimously support the Pohnpei Watershed Forest Reserve. In partnership with Pohnpei State Department of Land and Natural Resources, the Conservation Society of Pohnpei recently contracted a local private surveyor, Pacific Survey, Ltd., to delineate and mark the Pohnpei Watershed Forest Reserve. The entire watershed forest reserve boundary is 63,221 $\mathrm{m}$ long and it will cost US\$120,000 to complete the survey. The Pohnpei State Government appropriated this amount in their 2003 budget, and the Conservation Society of Pohnpei is currently completing a new contract with the surveyor to complete the line in 2004 (Anonymous 2003a). The delineation, which is well under way, and subsequent enforcement of the watershed forest reserve boundary, in conjunction with the sakau Grow Low Campaign, will greatly reduce agricultural clearing, hunting, and homestead development within the watershed forest reserve. In addition, it will help discourage road construction in the watershed forest reserve vicinity. Moreover, as noted earlier, the decreased human activity in the reserve will slow the introduction and spread of invasive plants and animals.

\section{Strategy 4. Lowland Sakau Certification Program}

Advocates of forest conservation and biodiversity protection on Pohnpei support the establishment of a "certified low-growth" sakau program, perhaps patterned after a program run by the "Rainforest Alliance" called the "ECO-OK" program. If successful, a "certified low-growth" product could command a premium price. Creating an eco-friendly "brand name" would also help differentiate sakau from Pohnpei from products of other producers. This could become important if lower-cost sources from other countries come into the market over the next 3-5 yr. By closing the commercial market for sakau cultivated in upland forest areas, the project will discourage further agricultural clearing. The Nature Conservancy has taken the lead in this initiative so far but will need the support of both the Pohnpei State Government (especially the Department of Economic Development and the Pohnpei State Legislature) and the island's sakau growers, who will need to self-police this certification program.

\section{Strategy 5. Community Planning by Municipality}

To help Pohnpeians create conservation strategies that address the shared concerns of the community, The Nature Conservancy helped launch a "Community Visioning Initiative" for the island in 2000. Visioning is 
an innovative process by which a community envisions the future it wants and plans how to achieve it. Through public involvement, communities identify their purpose, core values, and vision of the future, which are then transformed into a manageable set of community goals and an action plan. In March 2000, The Nature Conservancy sponsored a very successful visit by six Pohnpei leaders to community groups in Hawai' $i$ to see the community visioning process firsthand. After their return, the leaders organized a Community Visioning Workshop on Pohnpei for more than 80 people representing Pohnpei's 11 municipalities, women and youth groups, private business leaders, and other stakeholders. After the workshop, the municipalities of $\mathrm{U}$, Madolenihmw, and Nett along with the city of Kolonia launched visioning processes in their respective communities.

At the municipal level, the community visioning process helps the local community discuss and come up with solutions to key problems or threats. The planning program has already generated locally initiated solutions to agricultural clearing, hunting, homestead development, and road construction. The Nature Conservancy continues to be the lead agency in this strategy, though efforts are under way to pass the lead to a steering committee of municipal representatives and resource agencies (possible agencies include The Nature Conservancy, the Conservation Society of Pohnpei, the U.S. Department of Agriculture Natural Resources Conservation Service, Department of Health, Department of Education, Chief Magistrate's Council, Pohnpei Visitor's Bureau, Lieutenant Governor, Department of Land and Natural Resources, and others) to provide financial, process, advocacy, and peer coaching support to municipalities undergoing the process.

\section{Strategy 6. Monitoring of Sakau Cultivation and Dissemination of Information}

As part of the 3-yr grant funded by the United Nations Development ProgramGlobal Environment Facility, The Nature Conservancy implemented its "Community Conservation and Compatible Enterprise Development on Pohnpei, FSM" and began biennial monitoring of forest clearing activity to monitor the impacts of the Grow Low Campaign and other elements of the sakau strategy (Community Planning Program, Community Conservation Officer Program, watershed forest reserve boundary line survey, etc.). The monitoring has now been taken over by the Conservation Society of Pohnpei. The monitoring program is focusing on 13 forest areas representing the most ecologically important components of the Pohnpei Watershed Forest Reserve. Each of the selected forest areas shares a common upper border at the Nahna Laud ridge, the central peak of Pohnpei Island. Two individuals from each area have been selected by their village leaders to do the actual recording of forest clearing plots every 6 months. All information is analyzed and a report is produced by the Conservation Society of Pohnpei and shared with key government and traditional leaders to assist them in management or decision making that affects their forest resources.

Monitoring results for September 2003, undertaken, as usual, in selected areas around Pohnpei chosen for their biodiversity and their vital relations to the watershed, indicated that for the most part, "the clearing sites have dramatically decreased in size since the first quarter of 2003" with the largest decreases in the municipalities of $U$ and Madolenihmw, where the watershed forest reserve demarcation had already taken place (Anonymous 2003b). This monitoring program makes government and traditional leaders more aware of the serious threat from agricultural clearing and helps build consensus for protection of the watershed forest reserve.

\section{Strategy 7. Improve Agroforestry Productivity}

Much of the island's lowland agroforests have become neglected in recent years as rural people have embraced the cash economy and chosen wage labor over farming. By integrating cash crops (sakau, betel nut, betel leaf, kehp en dol yam cultivar, taro, menible banana cultivar, etc.) back into the traditional agroforestry system, it is expected that farmers will spend more effort on their farms. In turn, this will increase both household in- 
come and, indirectly, subsistence food production and income substitution, because the recommended cash crops need to be intercropped with local food crops such as breadfruit, taro, banana, yam, etc. In addition, women and elderly farmers will be able to participate in the cultivation of sakau for both traditional use and cash. Currently, $s a-$ kau production in the upland forests excludes these groups and further marginalizes them.

Improved agroforestry will not only increase local production of food and increase household income, but will also help slow agricultural clearing, hunting, homestead development, and the introduction of invasive plants and animals in the watershed forest reserve.

The Pohnpei Department of Economic Development, especially the Division of Agricultural Development, is leading this strategy currently, assisted by The Nature Conservancy, the Conservation Society of Pohnpei, the U.S. Department of Agriculture Natural Resources Conservation Service, Pohnpei Agricultural Trade School, and the College of Micronesia Land Grant Programs.

\section{Strategy 8. Enforce No-Burning Laws}

Pohnpei has established a law making it illegal to burn savanna/grasslands at any time; however, this law has not been enforced to date. By limiting the nearly annual burning of savanna/grasslands, the Pohnpei shorteared owl's nesting and hunting habitat will be protected. The Pohnpei Division of Forestry and Resource Conservation has taken a lead in enforcement of no-burning laws but needs better support from the municipal government and police to limit human-initiated fires.

MONITORING PROTOCOL, INITIAL

SUCCESSES, AND THE POTENTIAL ROLE OF

PABITRA IN POHNPEI RESOURCE

MANAGEMENT

The monitoring approach that The Nature Conservancy and its current governmental and nongovernmental organization partners is now conducting on Pohnpei was developed by a team of outside and local experts, and was documented in an August 1997 report entitled "Monitoring to Manage: A Report for Pohnpei's Watershed Management Program Team and Partners." The study was supported by The Nature Conservancy, the South Pacific Regional Environmental Programme, and the Rodney Johnson-Katherine Ordway Stewardship Endowment, an internal grant program in The Nature Conservancy dedicated to improving environmental management. The main objective of the study was to design a community-based monitoring program that is both resource-efficient and practical and that feeds directly into management decision making. The monitoring protocol, which focused on recording forest clearings, was piloted by The Nature Conservancy in 1998 in two forest areas, Senpehn in Madolenihmw District, and Eirike in Nett District. In addition to forest clearing, The Nature Conservancy also completed new aerial photography and vegetation analysis in 2002 (results discussed earlier) and is working with a host of partners to repeat an islandwide forest bird survey within the next $2 \mathrm{yr}$.

Several other suggestions have been entertained by The Nature Conservancy in various reviews of this site conservation plan, including monitoring of regeneration plots in abandoned agricultural clearings; establishment of plots to measure species composition and regeneration (succession) structure; focused bird monitoring (e.g., in recovering forest areas), including breeding and nonbreeding seasons, mist netting, mark and release, indicator species, bird movement; threats monitoring (invasive animals, hunting, agricultural clearing); water quality and fauna monitoring in headwater streams (e.g., point-source monitoring, mapping of threats, quantitative analysis, stream fauna, chemistry, sediment load, etc.); bat monitoring (recommended to be done on at most a 3-yr interval [best once/ month or twice/year] with counts at roosting sites at dusk [wet and dry seasons]); and intervention in the spread of invasive species (drop traps, ground traps, and removal of invasive alien plants).

However, with the current limited staff and financial resources, these monitoring and 
other activities remain only on the "wish list" for the resource managers pursuing goals through the strategies outlined here. One of the most promising scientific initiatives that could assist in these conservation-oriented monitoring and other activities on Pohnpei is the PABITRA network. Indeed, the island of Pohnpei has been proposed as a PABITRA site for ecological transect monitoring. Pohnpei, one of the few central Pacific high islands, is particularly well suited for inclusion in PABITRA. One of only three islands in the Pacific over 5 million yr old that still has substantial forest cover, Pohnpei is home to a relatively rich diversity of plant and animal species. In addition, for well over a decade, the island has been the focus of a major international effort to create a model of sustainable forest management; thus abundant scientific data are already available to assist in the establishment of permanent sites along transects within selected watersheds. Pohnpei offers potential vertical transects from the montane cloud forests and upland palm and broadleaf forests located on mountain peaks down through secondary forest, agroforest, swamp forest, and finally extensive coastal mangroves and fringing coral reefs. There is also considerable government and landowner awareness and support for conservationrelated activities on Pohnpei. In sum, the unique and abundant biodiversity of Pohnpei, combined with the availability of a sound biological and physical environmental database, along with ongoing government, community, and nongovernmental organization involvement in forest management, make this tropical island an obvious and particularly worthy candidate for inclusion in the PABITRA network.

\section{ACKNOWLEDGMENTS}

We thank the governments of the F.S.M. and Pohnpei State, The Nature Conservancy, the Conservation Society of Pohnpei, the South Pacific Regional Environmental Programme, the Asian Development Bank, Dieter Mueller-Dombois, Curt Daehler, and the many Pohnpeian people who offered their support and contributed to this study.

\section{Literature Cited}

Anonymous. 2003a. Marking the WFR boundary. The Messenger-Serehd: Conservation Society of Pohnpei Newletter 5 (3).

. 2003b. Forest monitoring in September. The Messenger-Serehd: Conservation Society of Pohnpei Newletter 5 (4).

Anson, H., and W. Raynor. 1993. Traditional resource management and the conservation of biological diversity on Pohnpei Island, Federated States of Micronesia. Pages 133-146 in L. Hamilton, ed. Ethics, religion and biodiversity: Relations between conservation and cultural values. The White Horse Press, Cambridge, U.K.

Ashby, G. 1990. A guide to Pohnpei: An island argosy. Rainy Day Press, Eugene, Oregon.

Buden, D. W. 1996. Rediscovery of the Pohnpei Mountain Starling (Aplonis pelzelni). Auk 113 (1): 229-230.

Buden, D. W., D. B. Lynch, and R. E. Watson. 2001. The gobiid fish (Teleostei: Gobioidei: Sicydiinae) of the headwater streams of Pohnpei, Eastern Caroline Islands, Federated States of Micronesia. Micronesica 34 (1): 1-10.

Dahl, C., and B. Raynor. 1996. Watershed planning and management: Pohnpei, Federated States of Micronesia. Asia Pac. Viewpoint 37 (3): 235-251.

Eldredge, L. G., and B. D. Smith. 1994. Introductions and transfers of the triclad flatworm Platydemus manokwari. Tentacle 4:8.

Engbring, J., F. Ramsey, and V. Wildman. 1990. Micronesian forest bird surveys; the Federated States: Pohnpei, Kosrae, Chuuk, and Yap. U.S. Fish and Wildlife Service, Honolulu, Hawai'i.

F.S.M. 2000. Census of population and housing, Pohnpei, Federated States of Micronesia.

Lebot, V., M. Merlin, and L. Lindstrom. 1992. Kava: The Pacific drug. Yale University Press, New Haven.

Merlin, M., D. Jano, B. Raynor, T. Keene, J. Juvik, and B. Sebastian. 1992. Tuhke en Pohnpei; Plants of Pohnpei. East-West 
Center, Program on Environment, Honolulu, Hawai'i.

Paulay, G. 1994. Biodiversity on oceanic islands: Its origin and extinction. Am. Zool. 34:134-144.

Raynor, W. 1994. Resource management in upland forests of Pohnpei: Past practices and future possibilities. ISLA: A Journal of Micronesian Studies (Rainy Season) 2 (1): 47-66.

Reisenberg, S. 1968. The native polity of
Ponape. Smithsonian Institution Press, Washington, D.C.

Schultes, R. E., A. Hofmann, and C. Rätsch. 2001. Plants of the gods: Their sacred, healing and hallucinogenic powers. Healing Arts Press, Rochester, Vermont.

Wiles, G. J., D. W. Buden, and D. J. Worthington. 1999. History of introduction, population status and management of Philippine deer (Cervus mariannus) on Micronesian islands. Mammalia 63 (2): 193-215. 